\title{
Juvenil myoklonusepilepsi
}

\begin{abstract}
Sammendrag
Bakgrunn. Juvenil myoklonusepilepsi (JME) er en generalisert epilepsi som debuterer $\mathrm{i}$ ungdomsårene. Formålet med denne artikkelen er å presentere oppdatert kunnskap om etiologi, diagnostikk og behandling av denne epilepsiformen.
\end{abstract}

\section{Kunnskapsgrunnlag. Artikkelen er} basert på et skjønnsmessig utvalg av engelskspråklige originalartikler, metaanalyser og oversiktsartikler funnet i PubMed, og på forfatternes egne erfaringer med pasientgruppen.

Resultater. Alle pasientene har myoklonier, rundt $90 \%$ har generaliserte tonisk-kloniske anfall, og ca. $30 \%$ har også absenser. Myokloniene, som gjerne debuterer i tenårene, kommer som regel før krampeanfallene. Pasientene er særlig anfallsutsatte rett etter oppvåkning. Det er viktig å spørre spesifikt om myoklonier, da pasientene ofte ikke rapporterer om dette spontant. EEG viser utbrudd av generaliserte $3-6 \mathrm{~Hz}$ polyspike-waves hos 44-81\%. Rundt $30 \%$ har fokale EEGfunn. Ved å bruke valproat og unngå anfallsutløsende faktorer, særlig søvnmangel, blir rundt $80 \%$ anfallsfrie. Lamotrigin eller levetiracetam er foreløpig alternativ behandling for kvinner i fertil alder. Det er høy risiko for anfallsresidiv ved seponering av medikamentene.

Fortolkning. På grunn av fokale trekk i anfallsutformingen og/eller EEG, kan denne epilepsiformen være vanskelig å diagnostisere. Mange blir mistolket til å ha en fokal epilepsi og får dermed en behandling som kan forsterke anfallstendensen.

\author{
Marte Roa Syvertsen \\ marsyv@vestreviken.no \\ Nevrologisk avdeling \\ Drammen sykehus
}

\section{Rune Markhus}

Avdeling for kompleks epilepsi

Klinikk for kirurgi og nevrofag

Oslo universitetssykehus

\section{Kaja Kristine Selmer}

Avdeling for medisinsk genetikk

Klinikk for diagnostikk og intervensjon Oslo universitetssykehus

\section{Karl O. Nakken}

Avdeling for kompleks epilepsi Klinikk for kirurgi og nevrofag Oslo universitetssykehus

Epilepsi deles i to hovedformer: fokal og generalisert. Ved fokale epilepsier er den epileptiske aktiviteten begrenset til én hemisfære, mens ved de generaliserte er begge hemisfærer involvert. Av de idiopatiske generaliserte epilepsiene, som utgjør 15-20\% av alle epilepsier, er juvenil myoklonusepilepsi (JME) og absensepilepsi de vanligste (1). Formålet med denne oversikten er å presentere oppdatert kunnskap om etiologi, patofysiologi, diagnostikk og behandling ved juvenil myoklonusepilepsi.

\section{Kunnskapsgrunnlag}

Artikkelen bygger på forfatternes kliniske erfaring med pasientgruppen, samt et skjønnsmessig utvalg av engelskspråklige originalartikler, metaanalyser og oversiktsartikler funnet i PubMed ved hjelp av kombinerte søkeord som «juvenile myoclonic epilepsy», «myoclonic epilepsy», «myoclonic jerks», «idiopathic generalized epilepsy» og «epilepsy in adolescence». Søket ble avsluttet 31.8. 2011.

\section{Historikk}

Juvenil myoklonusepilepsi ble først beskrevet av franskmannen Théodore Herpin (1799-1865) i 1867 (2). Først 90 år senere, i 1957, publiserte Janz \& Christian sin klassiske artikkel om det de den gang kalte impulsiv petit mal (3). Dette var den første omfattende beskrivelsen av kliniske manifestasjoner og EEG-funn ved syndromet. Artikkelen fikk imidlertid liten oppmerksomhet utenfor Tyskland. Selve begrepet juvenil myoklonusepilepsi ble først tatt i bruk i Danmark i 1975 (4). I 1980-årene ble syndromet «gjenopp- daget» i USA $(5,6)$, og i 1989 ble det inkludert i International League Against Epilepsys klassifikasjon av epileptiske syndromer (7). En annen betegnelse som blir brukt er Janz' syndrom.

\section{Klassifisering og epidemiologi}

Juvenil myoklonusepilepsi sorterer under de idiopatiske generaliserte epilepsiene (7). Det karakteristiske ved syndromet er at det $\mathrm{i}$ tidlige tenår dukker opp myoklonier ved oppvåkning og etter hvert også generaliserte tonisk-kloniske anfall.

Den eksakte prevalensen i den generelle befolkningen er ikke kjent. De få epidemiologiske studiene som er gjort, indikerer at dette syndromet utgjør rundt $8 \%(3-12 \%)$ av alle epilepsiene (8). Dette tilsvarer ca. 3200 personer i Norge.

\section{Etiologi}

Janz \& Christian fant i sitt klassiske materiale en forekomst av epileptiske anfall hos $17 \%$ av nærmeste familie til pasienter med juvenil myoklonusepilepsi (3). Senere studier viser at risikoen for idiopatisk epilepsi hos førstegradsslektninger av disse pasientene ligger i området 5-8\% (9). Den underliggende genetiske disposisjonen har derfor lenge vært kjent, men de faktiske genetiske variantene og mutasjonene har vært vanskelige å identifisere. Juvenil myoklonusepilepsi viser oftest en genetisk kompleks arvegang. For disse formene av syndromet har man funnet assosiasjon med varianter i flere genetiske områder, bl.a. et kromosomområde på 6 p21 (10), et område nær genet BRD2 (bromodomain containing 2) (11) og en mikrodelesjon på kromosomområde $15 q 13.3$ (12). Felles for disse studiene er at de identifiserte genvariantene finnes oftere hos pasienter med juvenil myoklonusepilepsi enn hos friske individer. Hvilket gen eller hvilken variant fra hvert av områdene som faktisk forårsaker risikoøkning for sykdom-

\section{Hovedbudskap}

- Juvenil myoklonusepilepsi er et epilepsisyndrom som debuterer i tenårene og utgjør rundt $8 \%$ av alle epilepsier

- For å stille rett diagnose er det særlig viktig å spørre spesifikt etter myoklonier

- Med riktig behandling kan mer enn $80 \%$ av pasientene bli anfallsfrie 
men, er imidlertid ennå ikke sikkert. En undergruppe av pasientene viser monogen arvegang, dvs. at juvenil myoklonusepilepsi hos disse pasientene er forårsaket av mutasjon i ett gen alene. Flere sjeldne former for monogen type er blitt beskrevet, oftest med autosomalt dominant arvegang $(13,14)$.

Selv om genetiske funn per i dag ikke er anvendelig i diagnostisk sammenheng, kan de involverte genene gi oss hint om den bakenforliggende patofysiologien. Disse genene koder blant annet for subenheter av ionekanaler, proteiner som påvirker ionekanaler og proteiner involvert $\mathrm{i}$ apoptose $(13,14)$.

\section{Patofysiologi}

De patofysiologiske mekanismene er ikke kjent. Det er imidlertid visse holdepunkter for at det forekommer lette funksjonelle og strukturelle avvik, særlig i frontallappene, i mindre grad også ekstrafrontalt (15). Nevropsykologiske studier har vist at noen pasienter med juvenil myoklonusepilepsi skårer dårligere enn kontrollpersonene på tester av frontallappsfunksjoner, for eksempel begrepsdannelse, planlegging og mental fleksibilitet og hurtighet (15). Det er også funnet økt forekomst av lette personlighetsavvik (16). Fra et patofysiologisk ståsted er dette interessante resultater, men funnene er såpass beskjedne og uspesifikke at nevropsykologisk testing ikke inngår i standardutredningen av syndromet.

Ved avanserte avbildningsteknikker er det funnet avvik i nevrontetthet, særlig i mediale deler av frontallappene, men også i thalamus og i frontotalamiske baner $(17,18)$. Man har derfor lurt på om juvenil myoklonusepilepsi kan skyldes en forstyrrelse i det frontotalamiske cellenettverket, muligens på bakgrunn av en genetisk betinget mikrodysgenesi (19).

Med funn som peker i retning av frontal dysfunksjon, dvs. et fokalt trekk, hos pasienter med en generalisert epilepsiform som juvenil myoklonusepilepsi, utfordres den tradisjonelle dikotomien «fokale» og «generaliserte» epilepsier.

\section{Klinisk ytringsform \\ Myoklonier}

Myoklonier forekommer hos alle pasientene og er med på å definere syndromet $(5,6,20)$. Myokloniene ytrer seg som plutselige rykk i muskulaturen, vanligvis bilateralt og proksimalt i overekstremitetene. De kan også affisere distal muskulatur, for eksempel i hendene eller i underekstremitetene. Rykkene kan av og til være asymmetriske. Enkelte pasienter betegner dem som små elektriske støt, og de kan variere i styrke. Av og til er de så kraftige at pasienten plutselig mister det han holder i hendene eller faller. Anfallene regnes som generaliserte selv om bevisstheten er upåvirket. Myoklonier er som rege debutsymptomet og kommer gjerne rundt 12-14 års alder blant jenter og rundt 14-16 års alder blant gutter $(5,21,22)$.
Generaliserte tonisk-kloniske anfall (GTK) Ca. $90 \%$ av pasientene har generaliserte tonisk-kloniske anfall (21-23). Etter å ha tolket myokloniene som utslag av nervøsitet eller uro, er det gjerne et krampeanfall som bringer pasienten til lege eller sykehus (21, 22). Pasienter som kun har myoklonier, kan forbli udiagnostiserte. Krampeanfallene kommer som regel noen måneder etter debut av myoklonier, men hos noen kan det gå flere år $(5,20)$. En serie av myoklonier kan varsle et generalisert tonisk-klonisk anfall, som da blir å betrakte som et klonisk-tonisk-klonisk anfall $(6,22)$. Hos ca. $30 \%$ kan krampeanfallene ha en fokal innledning med for eksempel en vridning av hodet mot en side (21).

\section{Absenser}

Rundt en tredel av pasientene har også absenser (21-23). Absenser er kortvarige episoder med nedsatt bevissthet uten andre ledsagesymptomer. Pasienten stirrer tomt fremfor seg, svarer ikke på tiltale og kan stoppe opp midt $i$ en handling eller en setning. Absenser forekommer særlig blant dem som har en tidlig symptomdebut (5, 21). Rundt $15 \%$ får absenser i barneårene før det dukker opp andre anfallstyper (24). Absensene er kortvarige og frekvensen kan være så lav at de ikke oppdages.

\section{Døgnvariasjon}

Typisk for juvenil myoklonusepilepsi er at anfallstendensen er størst rett etter oppvåkning (21). Det gjelder for så vel myoklonier som generaliserte tonisk-kloniske anfall. Mange får derfor anfall under morgentoalettet eller under frokosten. Pasientene kan også få anfall etter søvn på dagtid. Ca. $15 \%$ får anfall til alle tider av døgnet $(21,22)$.

\section{Anfallsutløsende faktorer}

Mange av pasientene er særlig anfallsutsatte ved søvnmangel. En norsk studie viste at dette gjaldt $83,7 \%$ (25). Andre anfallsutløsende faktorer er alkoholinntak, menstruasjon, utmattelse, stress, spenninger, frustrasjon og medisinforglemmelse. Klinisk fotosensitivitet, dvs. anfall utløst av flimrende lys, ses hos rundt $5 \%$, mens fotoparoksysmal respons på EEG, dvs. epileptisk aktivitet fremkalt av flikkerstimulering, ses hos $30-40 \%(21,22,25,26)$

\section{Utredning}

Utredning og behandling bør skje i regi av nevrolog eller barnenevrolog. Viktigst er en grundig sykehistorie, inkludert komparentopplysninger. Spesielt må man spørre etter myoklonier, noe de færreste pasienter regner som anfall og ikke forteller om spontant.

Hos $44-81 \%$ av pasientene finnes et patologisk EEG med utbrudd av generalisert 3-6 $\mathrm{Hz}$ polyspike-waves som det mest typiske, noe som anses som patognomonisk for syndromet (26). Aktiviteten er mest uttalt frontalt. Bakgrunnsaktiviteten er vanligvis normal (figur 1). Av og til må pasientene søvndepriveres for å få frem de typiske EEG-forstyrrelsene. Jo flere EEG-registreringer som gjøres, jo høyere andel av pasientene har typiske EEG-funn.

Helt normale interiktale EEG-funn, selv etter sønvdeprivasjon, er funnet hos ca. $40 \%$ (27), og fokale patologiske endringer i EEG er rapportert å forekomme hos rundt $30 \%$ $(8-55 \%)(5,21,22,25)$. En slik fokalitet kan lett gi opphav til feil diagnose (26). Ved mistanke om juvenil myoklonusepilepsi bør det derfor tas EEG med flikkerstimulering, ev. med søvndeprivasjon. Ved manglende funn i EEG, bør undersøkelsen gjentas, ev. flere ganger. De typiske EEG-forandringene er ikke obligat for å stille diagnosen.

Klinisk nevrologisk undersøkelse og cerebral MR er normal $(20,21)$. Er man usikker på diagnosen, særlig ved opptreden av fokale trekk i anfallsutformingen eller i EEG, bør cerebral MR inkluderes i utredningen.

\section{Differensialdiagnoser}

Pasienter med juvenil myoklonusepilepsi får ofte feil diagnose, selv av erfarne nevrologer $(28,29)$. Det vanligste er at myokloniene blir oversett. Mange av pasientene blir feildiagnostisert til å ha en fokal epilepsi av ukjent årsak. Dette fordi myokloniene kan være asymmetriske, de generaliserte toniskkloniske anfallene kan ha en fokal innledning, EEG kan fremvise fokale patologiske endringer, og absenser kan mistolkes som komplekse partielle anfall.

Juvenil absensepilepsi likner både klinisk og elektroencefalografisk, men myokloniene er mindre fremtredende enn ved juvenil myoklonusepilepsi, og pasientene mangler ofte den typiske døgnvariasjonen i anfallsopptredenen (24).

Myoklonier kan forekomme uten at de er ledd i epilepsi, for eksempel ved anoksisk hjerneskade, hjernestammelesjoner, eller som innsovningsmyoklonier - som er et normalt fenomen.

Progredierende myoklonusepilepsi kan i startfasen misoppfattes som juvenil myoklonusepilepsi. Etter hvert kommer det imidlertid nevrologiske symptomer som kognitiv svikt og ataksi, noe man ikke ser ved juvenil myoklonusepilepsi (30).

\section{Behandling}

Valproat har i mange år vært førstevalg i behandlingen. Dette ble understøttet av en åpen, prospektiv, randomisert kontrollert studie av 716 pasienter med idiopatisk generalisert eller uklassifiserbar epilepsi. Valproat ga bedre anfallskontroll enn lamotrigin og topiramat (31). Rundt $80 \%$ av pasientene med juvenil myoklonusepilepsi blir anfallsfrie på valproat $(6,22,32)$. Dersom pasienten ikke blir anfallsfri på valproat i monoterapi, er det mindre sannsynlighet for at man kommer til målet med et annet medikament i monoterapi (33).

Valproat brukt under svangerskapet gir $ø \mathrm{kt}$ risiko for misdannelser hos barnet og bør 

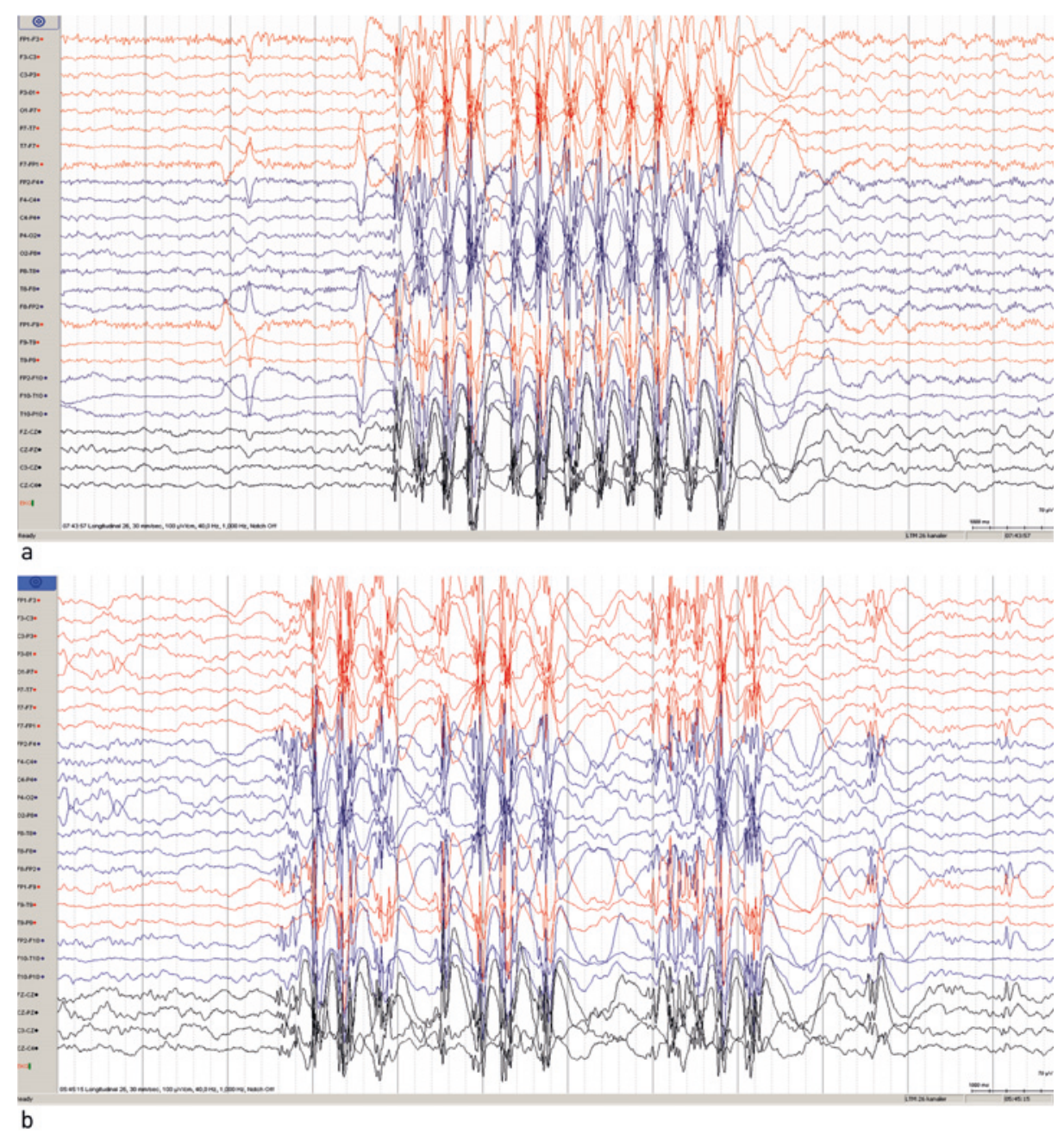

Figur 1 EEG fra en ung gutt med juvenil myoklonusepilepsi. Kurvene viser utbrudd av $3 \mathrm{~Hz}$ generaliserte polyspike-waves al i våken tilstand og b) under lett søvn

derfor unngås hos fertile kvinner (34). Valproat kan også gi endokrine og metabolske forstyrrelser. Unge kvinner er spesielt utsatt for slike bivirkninger, som bl.a. kan føre til polycystisk ovariesyndrom og overvekt (35). Lamotrigin eller levetiracetam kan være gode alternativ, men lamotrigin kan forverre myoklonier $(36,37)$. Det er publisert data som kan indikere en sammenheng mellom plutselig død (SUDEP) blant unge kvinner med generalisert epilepsi og bruk av lamotrigin (38). Tallmaterialet er imidlertid lite, og andre forfattere har ikke kunnet finne en slik sammenheng. (39). Dersom det ikke oppnås kontroll over de generaliserte toniskkloniske anfallene med annen medikasjon, bør valproat likevel brukes, men i så lave doser som mulig. Generaliserte tonisk-kloniske anfall i første trimester av svangerskapet anses å være en større risiko for fosteret enn valproateksponeringen (34).

Generelt anbefaler vi oppstart med valproat til alle, unntatt kvinner i fertil alder. Hos kvinner med ønske om barn anbefaler vi bruk av levetiacetam eller lamotrigin, dette inntil vi får sikrere data på om det er en årsakssammenheng mellom bruk av lamotrigin og plutselig død hos disse pasientene.
Topiramat er et potent antiepileptikum, også ved juvenil myoklonusepilepsi, men tolereres ofte dårlig, særlig i litt høye doser (31). Topiramat er derfor ikke førstevalg, men kan benyttes hos pasienter med tilleggsproblemer som migrene eller overvekt. Zonisamid kan også forsøkes, selv om evidensnivået for effekt foreløpig er lavt (40). Klonazepam kan ha god effekt mot myoklonier, men forebygger bare i liten grad generaliserte tonisk-kloniske anfall (41). Primidon og sultiam er rapportert å ha effekt i enkelttilfeller $(20,42)$. Dersom det ikke oppnås anfallsfrihet med monoterapi, kan en kombinasjon av valproat og lamotrigin forsøkes. Dersom myokloniene er det mest fremtredende, er en kombinasjon av valproat og klonazepam verdt å forsøke.

Karbamazepin, fenytoin, gabapentin, tiagabin og vigabatrin bør unngås hos pasienter med juvenil myoklonusepilepsi fordi de alle kan gi anfallsøkning, særlig av myoklonier og absenser (43).

Ved siden av medikamentell behandling kontrollen, først og fremst gjennom å unngå søvnmangel og stort inntak av alkohol, samt å huske å ta medikamentene regelmessig (40). kan pasientene selv bidra til å bedre anfalls-

\section{Prognose}

Majoriteten av pasienter med juvenil myoklonusepilepsi er farmakosensitive og oppnår anfallsfrihet med riktig medikasjon. En liten undergruppe på ca. $15 \%$ er imidlertid farmakoresistente (44). Ved siden av økt risiko for tilleggsproblemer av kognitiv, atferdsmessig eller psykiatrisk art, har disse en økt risiko for plutselig og uventet død (45).

Det har lenge vært en alminnelig oppfatning at syndromet er en livslang tilstand. Anfallstendensen ser likevel ut til å bli svakere etter fylte 40 år, og myokloniene blir borte med årene. Risikoen for residiv ved å seponere medikasjonen er imidlertid høy, rundt $90 \%(6,20,22,32)$. En fersk studie fra Nova Scotia viste noe overraskende at 11 av 23 pasientene med juvenil myoklonusepilepsi var uten antiepileptika 20 år etter anfallsdebut. Av disse var seks anfallsfrie, tre hadde kun myoklonier og to hadde svært sjelden anfall (46). Det kan derfor være riktig å diskutere muligheten av seponering med pasienter som har vært anfallsfrie i mange år, men de må informeres om risikoen for anfallsresidiv.

De aller fleste pasientene med syndromet lever fullverdige liv med få eller ingen restriksjoner i levesettet (25).

\section{Konklusjon}

Juvenil myoklonusepilepsi er stadig underdiagnostisert $(28,29)$. Blant dem som făr diagnosen, er det funnet en forsinket diagnostikk på rundt ni år (29). Det er viktig å spørre spesifikt etter myoklonier, da pasientene ofte ikke rapporterer om dette spontant. Typisk er det at pasientene er særlig anfallsutsatte rett etter oppvåkning. Søvnmangel senker anfallsterskelen hos de fleste. Funn av generaliserte utbrudd av 3-6 Hz polyspike-waves sikrer diagnosen. De fleste responderer godt på valproat, men får ofte tilbakefall ved forsøk på seponering. Feildiagnostisering kan få alvorlige konsekvenser, med økt anfallstendens, i verste fall status epilepticus.

\section{Marte Roa Syvertsen (f. 1982)}

er lege i spesialisering ved Nevrologisk avdeling, Drammen sykehus.

Forfatter har fylt ut ICMJE-skjemaet og oppgir ingen interessekonflikter.

\section{Rune Markhus (f.1961)}

er spesialist i nevrologi og i klinisk nevrofysiologi. Han er seksjonsleder ved Klinikk for kirurgi og nevrofag, Avdeling for kompleks Epilepsi-SSE, Oslo universitetssykehus.

Forfatter har fylt ut ICMJE-skjemaet og oppgir ingen interessekonflikter. 


\section{Kaja Kristine Selmer (f. 1974}

er dr.med. i emnet epilepsi og genetikk. Hun jobber som postdoktor ved Avdeling for medisinsk genetikk, Oslo universitetssykehus. Forfatter har fylt ut ICMJE-skjemaet og oppgir følgende interessekonflikter: Hun har mottatt foredragshonorar fra UCB.

\section{Karl Otto Nakken (f. 1945)}

er dr.med., spesialist i nevrologi og medisinsk sjef ved Avdeling for kompleks epilepsi-SSE, Oslo universitetssykehus.

Forfatter har fylt ut ICMJE-skjemaet og oppgir ingen interessekonflikter.

\section{Litteratur}

1. Jallon P, Latour P. Epidemiology of idiopathic generalized epilepsies. Epilepsia 2005; 46 Isuppl 9): $10-4$.

2. Eadie MJ. The epileptology of Théodore Herpin (1799-1865). Epilepsia 2002; 43: 1256-61.

3. Janz D, Christian W. Impulsiv petit mal. Dtsch Z Nervenheilkd 1957; 176: 346-86.

4. Lund M, Reintoft $H$, Simonsen N. En kontrolleret social og psychologisk undersogelse af patienten med juvenil myoclon epilepsi. Ugeskr Læger 1975; 137: 2415-8.

5. Asconapé J, Penry JK. Some clinical and EEG aspects of benign juvenile myoclonic epilepsy. Epilepsia 1984; 25: 108-14.

6. Delgado-Escueta AV, Enrile-Bacsal F. Juvenile myoclonic epilepsy of Janz. Neurology 1984; 34 : 285-94.

7. Commission on Classification and Terminology of the International League Against Epilepsy. Proposal for revised classification of epilepsies and epileptic syndromes. Epilepsia 1989; 30: 389-99.

8. Thomas P, Genton P, Gelisse P et al. Juvenile myo clonic epilepsy. I: Roger J, Bureau M, Dravet C et al, red. Epileptic syndromes in Infancy, Childhood and Adolescence. 3. opplag. Montrouge: John Libbey Eurotext, 2002; 335-56.

9. Pal DK, Pong AW, Chung WK. Genetic evaluation and counseling for epilepsy. Nat Rev Neurol 2010; 6: $445-53$

10. Greenberg DA, Durner M, Keddache M et al. Reproducibility and complications in gene searches: linkage on chromosome 6 , heterogeneity, association, and maternal inheritance in juvenile myoclonic epilepsy. Am J Hum Genet 2000; 66: 508-16.

11. Pal DK, Evgrafov OV, Tabares $P$ et al. BRD2 (RING3) is a probable major susceptibility gene for common juvenile myoclonic epilepsy. Am J Hum Genet 2003; 73: 261-70.

12. Helbig I, Mefford HC, Sharp AJ et al. 15q13.3 microdeletions increase risk of idiopathic generalized epilepsy. Nat Genet 2009; 41: 160-2.

13. Cossette P, Liu L, Brisebois K et al. Mutation of GABRA1 in an autosomal dominant form of juvenile myoclonic epilepsy. Nat Genet 2002; 31 . 184-9

14. Suzuki T, Delgado-Escueta AV, Aguan K et al. Mutations in EFHC1 cause juvenile myoclonic epilepsy. Nat Genet 2004; 36: 842-9.

15. Moschetta S, Fiore LA, Fuentes D et al. Personality traits in patients with juvenile myoclonic epilepsy. Epilepsy Behav 2011; 21: 473-7.

16. Devinsky O, Gershengorn J, Brown E et al. Frontal functions in juvenile myoclonic epilepsy. Neuropsychiatry Neuropsychol Behav Neurol 1997; 10: $243-6$.

17. Tae WS, Kim SH, Joo EY et al. Cortical thickness abnormality in juvenile myoclonic epilepsy. J Neurol 2008; 255: 561-6.

18. de Araújo Filho GM, Jackowski AP, Lin K et al. Personality traits related to juvenile myoclonic epilepsy: MRI reveals prefrontal abnormalities through a voxel-based morphometry study. Epilepsy Behav 2009; 15: 202-7.

19. Meencke HJ, Janz D. Neuropathological findings in primary generalized epilepsy: a study of eight cases. Epilepsia 1984; 25: 8-21.

20. Janz D. Juvenile myoclonic epilepsy. Epilepsy with impulsive petit mal. Cleve Clin J Med 1989; 56 (suppl Pt 1): S23-33, discussion S40-2.

21. Canevini MP, Mai R, Di Marco $C$ et al. Juvenile myoclonic epilepsy of Janz: clinical observations in 60 patients. Seizure 1992: 1:291-8.

22. Panayiotopoulos CP, Obeid T, Tahan AR. Juvenile myoclonic epilepsy: a 5-year prospective study. Epilepsia 1994; 35: 285-96.

23. Cvetkovska E, Panov S. Possible genetic anticipation in families with idiopathic generalised epilepsy. Epileptic Disord 2011; 13: 150-4.

24. Wirrell EC, Camfield CS, Camfield PR et al. Longterm prognosis of typical childhood absence epilepsy: remission or progression to juvenile myoclonic epilepsy. Neurology 1996; 47: 912-8.

25. Kleveland G, Engelsen BA. Juvenile myoclonic epi lepsy: clinical characteristics, treatment and prognosis in a Norwegian population of patients. Seizure 1998; 7: $31-8$

26. Dhanuka AK, Jain BK, Daljit $S$ et al. Juvenile myoclonic epilepsy: a clinical and sleep EEG study. Seizure 2001; 10: 374-8

27. Pedersen SB, Petersen KA. Juvenile myoclonic epilepsy: clinical and EEG features. Acta Neurol Scand 1998; 97: 160-3.

28. Atakli D, Sözüer D, Atay T et al. Misdiagnosis and treatment in juvenile myoclonic epilepsy. Seizure 1998; 7: 63-6

29. Vijai J, Cherian PJ, Stlaja PN et al. Clinical characteristics of a South Indian cohort of juvenile myoclonic epilepsy probands. Seizure 2003; 12: 490-6.

30. Satishchandra P. Sinha S. Progressive myoclonic epilepsy. Neurol India 2010; 58: 514-22.

31. Marson AG, Al-Kharusi AM, Alwaidh M et al. The
SANAD study of effectiveness of valproate, lamotrigine, or topiramate for generalised and unclassifiable epilepsy: an unblinded randomised controlled trial. Lancet 2007; 369: 1016-26.

32. Calleja S, Salas-Puig J, Ribacoba R et al. Evolution of juvenile myoclonic epilepsy treated from the outset with sodium valproate. Seizure 2001; 10 424-7.

33. Kwan P. Brodie MJ. Early identification of refractory epilepsy. N Engl J Med 2000; 342: 314-9.

34. Tomson T, Battino D, Bonizzoni E et al. Dosedependent risk of malformations with antiepileptic drugs: an analysis of data from the EURAP epilepsy and pregnancy registry. Lancet Neurol 2011; 10: $609-17$

35. Isojärvi J. Disorders of reproduction in patients with epilepsy: antiepileptic drug related mechanisms. Seizure 2008; 17: 111-9.

36. Bodenstein-Sachar H, Gandelman-Marton R, Ben-Zeev B et al. Outcome of lamotrigine treatment in juvenile myoclonic epilepsy. Acta Neurol Scand 2011; 124: 22-7.

37. Rosenfeld WE, Benbadis S, Edrich P et al. Levetiracetam as add-on therapy for idiopathic generalized epilepsy syndromes with onset during adolescence: analysis of two randomized, doubleblind, placebo-controlled studies. Epilepsy Res 2009: 85: 72-80.

38. Aurlien D, Taubøll E, Gjerstad L. Lamotrigine in idiopathic epilepsy - increased risk of cardiac death? Acta Neurol Scand 2007; 115: 199-203.

39. Hesdorffer DC, Tomson T, Benn E et al. Do antiepileptic drugs or generalized tonic-clonic seizure frequency increase SUDEP risk? A combined analysis. Epilepsia 2012; 53: 249-52.

40. Mantoan L, Walker M. Treatment options in juvenile myoclonic epilepsy. Curr Treat Options Neurol 2011; 13: 355-70.

41. Obeid T, Panayiotopoulos CP. Clonazepam in juvenile myoclonic epilepsy. Epilepsia 1989; 30: 603-6.

42. Lerman P, Nussbaum E. The use of sulthiame- in myoclonic epilepsy of childhood and adolescence. Acta Neurol Scand Suppl 1975; 60: 7-12.

43. Perucca E, Gram L, Avanzini G et al. Antiepileptic drugs as a cause of worsening seizures. Epilepsia 1998; 39: 5-17.

44. Gelisse P. Genton P. Thomas P et al. Clinical factors of drug resistance in juvenile myoclonic epilepsy. J Neurol Neurosurg Psychiatry 2001; 70: 240-3.

45. Shorvon S. Risk factors for sudden unexpected death in epilepsy. Epilepsia 1997; 38 (suppl): $\mathrm{S} 20-2$

46. Camfield CS, Camfield PR. Juvenile myoclonic epilepsy 25 years after seizure onset: a populationbased study. Neurology 2009; 73: 1041-5.

Mottatt 21.12. 2011, første revisjon innsendt 12.3. 2012, godkjent 10.5. 2012. Medisinsk redaktør

Merete Kile Holtermann. 